\title{
Apresentação dos Editores Convidados
}

\author{
JERÓNIMO PIZARRO E FILIPA FREITAS
}

Fernando Pessoa foi um homem dedicado a projectos dramatúrgicos. A datação dos seus textos, que a edição crítica tem permitido, revela que o interesse de Pessoa pelo teatro ocupou praticamente toda a sua vida. O conhecimento do acervo dramático de Pessoa tem suscitado, nos últimos anos, um crescente interesse, tanto do ponto de vista editorial, como do ponto de vista da investigação. As edições mais recentes procuraram responder às seguintes questões: Fernando Pessoa foi realmente um dramaturgo? Quantas peças de teatro Pessoa escreveu e quantos projectos foram abandonados? Pessoa revela um genuíno interesse pela dramaturgia ou apenas um entusiasmo momentâneo que se dissipa para dar lugar a outros projectos?

As edições que foram desenvolvidas nos últimos anos têm revelado uma faceta pouco conhecida do poeta, não só pela recuperação de textos outrora mencionados por diferentes investigadores, especialmente Teresa Rita Lopes (cuja investigação foi um contributo determinante para o desbravamento do caminho), mas também pela publicação de textos inéditos que se mantinham no espólio de Fernando Pessoa (depositado na Biblioteca Nacional de Portugal) e que tem vindo a aumentar o nosso conhecimento do teatro do poeta. Importa, por isso, fazer uma breve contextualização da história editorial da obra dramática de Fernando Pessoa.

Pessoa publicou, em vida, apenas uma peça, $O$ Marinheiro, em 1915, no primeiro número da revista Orpheu. Após a sua morte, em 1935, surgem as primeiras edições da sua obra, na editora Ática, mas somente em 1952 os leitores tiveram acesso a alguns fragmentos de outra peça, Fausto, editada por Eduardo Freitas da Costa. Mas foi necessário esperar até às décadas de 1970 e 1980 para conhecermos outras peças pessoanas, através das investigações de Teresa Rita Lopes: Sakyamuni, Salomé, Diálogo no Jardim do Palácio, A Morte do Príncipe e Calvário. Além da edição destes textos, Rita Lopes deu a conhecer ao público diversos títulos e pequenos fragmentos de peças ainda por editar no espólio pessoano.

Fausto, parcialmente publicado em 1952, recebeu nova atenção nas décadas subsequentes: Duílio Colombini, em 1986, Teresa Sobral Cunha, 
em 1988, e Carlos Pittella, em 2018, foram responsáveis por novas edições da peça. Com excepção de $O$ Marinheiro, que foi frequentemente reeditado, as outras peças de Pessoa ficaram praticamente esquecidas desde o trabalho de Teresa Rita Lopes. Somente em 2014 foi publicada uma nova edição da peça Inércia, por Luísa Monteiro, e, em 2017, um volume com as catorze peças do denominado teatro estático: O Marinheiro, Diálogo no Jardim do Palácio, A Morte do Príncipe, As Cousas, Diálogo na Sombra, Os Emigrantes, Inércia, A Cadela, Os Estrangeiros, Sakyamuni, Salomé, A Casa dos Mortos, Calvário e Intervenção Cirúrgica. Por fim, também em 2017, foi publicada outra peça inédita, intitulada $O$ Amor, na revista Pessoa Plural. Não obstante estas edições, um número significativo de textos dramáticos de Pessoa continua, ainda, inédito no espólio do poeta.

Se a edição em papel tem sido predominante na obra de Pessoa, algumas iniciativas diferentes tiveram lugar nos últimos anos. Em relação ao seu teatro, destacam-se dois projectos no Centro de Estudos de Teatro: a edição digital de Fausto e da Trilogia dos Gigantes. As ferramentas da edição digital permitiram, através destes projectos, abrir caminho para uma nova forma de editar a fragmentação do teatro pessoano.

Estas diferentes edições da obra pessoana (em papel e em formato digital) não dão conta, todavia, da investigação académica e não-académica que o conhecimento dos textos dramáticos tem suscitado. Não é possível, naturalmente, elencar os estudos que têm sido desenvolvidos neste âmbito, mas é importante frisar alguns encontros científicos mais recentes que têm alargado as investigações, promovidos pelo Centro de Estudos de Teatro: o primeiro, em 2018, resultante da edição digital de Fausto, reuniu diferentes estudiosos nacionais e internacionais em torno da peça pessoana, cujos contributos foram publicados na revista especializada Pessoa Plural (n. ${ }^{\circ}$ 14, Outono de 2018); o segundo, em 2019, dedicado à inédita Trilogia dos Gigantes, procurou alargar a interpretação dos temas presentes nas três peças mitológicas que compõem a Trilogia, reunindo investigadores não só dedicados aos estudos pessoanos e aos estudos de teatro, mas também à filologia, aos estudos clássicos e à filosofia. Os ensaios resultantes deste encontro serão publicados num número especial da Pessoa Plural.

Complementar a estas iniciativas dedicadas estritamente ao teatro de Fernando Pessoa, surge o presente número da revista Sinais de Cena, que procurou responder a uma questão pertinente: que ligação se pode estabelecer entre os textos dramáticos ou passíveis de dramaturgia de
Fernando Pessoa e a sua efectiva encenação? Até agora, as vozes dos investigadores procuraram maioritariamente analisar os textos teatrais de Pessoa enquanto manifestação de temas recorrentes na sua obra ou de intertextualidades que revelam as diferentes sementes que o poeta plantou e desenvolveu ao longo da sua vida. Referimo-nos a temas que caracterizam, sob diferentes formas (teatro, poesia, contos, narrativa), questões metafísicas fundamentais, nomeadamente o mistério do mundo, a dicotomia sonho/realidade, a possibilidade da loucura e a multiplicidade do sujeito. No entanto, se Pessoa escreveu textos dramáticos, em que medida se pode representar a obra pessoana? E se é passível de representação, que testemunhos nos podem dar os encenadores e actores que constroem o espectáculo e interpretam personagens tão fragmentadas como as que Pessoa nos deixou?

O dossiê especial que agora apresentamos na revista Sinais de Cena pretende iniciar esta ponte entre o texto e o espectáculo. Reúnem-se, neste número, diferentes artigos que propõem uma visão além do texto pessoano e que nos revelam o complexo mundo da representação do texto dramático de Fernando Pessoa, não só em Portugal, mas também além-fronteiras. Este novo contributo para os estudos de teatro (e para os estudos pessoanos) procurou, por conseguinte, alargar as possibilidades de interpretação do teatro de Fernando Pessoa. Da teoria à prática, o dossiê oferece uma visão diferente da que podemos encontrar na investigação académica, revelando, assim, que a obra dramática do poeta é um caminho sem fim, passível de ser sempre percorrido (e reinterpretado) por quem queira iniciar essa aventura. 